\title{
The Labeling of Good and Evil in "Descendants"
}

\author{
Alicia. \\ English Department, Faculty of Letters, Petra Christian University, Siwalankerto 121-131, Surabaya 60236, \\ East java, INDONESIA \\ E-mails: alicia.nagaseta@gmail.com
}

\begin{abstract}
This paper aims to discuss the instilment of good and evil as well as their effects to the royal and villains' children. I will use the theories of labeling, social identity, and self-concept to analyze the topic. Labeling theory is applied to analyze the ways the labels good and evil are formed through the parents' past interaction with each other before they instilled it to their children. Social identity theory is used to analyze the ways the children construct their identities depending on the social group they live in. Finally, selfconcept theory is applied in providing the ways that the labels good and evil shape the children's perspective and behavior toward themselves. In the end, it can be concluded that the labeling of good and evil in Descendants could be passed down from parents to children. The labels, along with social groups and other people's opinions could shape the children's self-concept about themselves.

Keywords: Labeling, Social Idenity, Self-Concept, Good, Evil.
\end{abstract}

The story of Descendants tells about the interaction of four children of Disney's villainous characters with the royal children in Auradon that raises the issue of labeling. The royal children are labeled as good children who deserve everything good because they are born from Disney princes and princesses. This then cause the royal children to be seen as good children even though they may have behaved badly. In contrast, the villains' children immediately receive the label of evil since they are born from Disney evil villains. The label of evil then expects the children to be evil like their parents without giving them the chance to be different. Thus, to analyze the labeling of good and evil between the royal and villain children, I will use labeling theory, social identity theory, and self-concept theory.

Labeling theory is a theory of how a person's self-identity and behavior are influenced by the terms or words that are used to describe them. Labeling could also be passed down from parents to children. According to the book Like Godfather, Like Son: Exploring the Intergenerational Nature of Crime written by Randi Hjalmarsson and Matthew J. Lindquist, parents could transmit the label they posses to their children through genetics and through the parents' conscious act in passing down his label's values to the children (Hjalmarsson, Lindquist, 2012). Therefore, I would like to reveal the ways that 'good' and 'evil' are instilled through labeling. Social identity theory is a theory that states that people define their own identities depending on social groups (Islam, 2014). Self-concept is a theory on the totality of an individual's thoughts and feelings having reference to himself as an object (Gecas, 1982). Self-concept is defined through the process of selfevaluation that is also known as self-esteem. The labeling, social identity, and self-concept theories would connect with each other to see how the label of good and evil could affect the royal and villain children's behavior and perception about each other.

\section{The Label of Good and Evil}

The formation of good and evil derives from the royal families and villainous characters' interactions with each other as told in each of the characters' stories in the Disney animated versions. The royal families, who are all the main characters in the Disney animated films, are all good people who never do anything to harm others. On the contrary, the villainous characters, also known as the antagonist of all Disney animated films, are considered evil since they harm the royal families. 
In the story of Descendants, the royal families still remember their experiences of the past encounters with the villainous characters that they put the label of evil to them. The labeling of evil then brings expectations, stereotype, and prejudice on how the villainous characters should behave according to the label given, which could be seen in the quotation where King Beast rejects his son's, Prince Ben's, proclamation to invite the children of the villainous characters to Auradon.

PRINCE BEN. I decided that the children on the Isle of the Lost be given a chance to live here in Auradon.

BELLE. (Disbelief) Huh? (Drops a vest on the floor.)

KING BEAST. The children of our sworn enemies living among us?

PRINCE BEN. We start out with a few at first, the ones that need our help the most. I've already chosen them.

KING BEAST. Have you?

BELLE. $\quad[. .$.$] Who are their parents?$

PRINCE BEN. Cruella De Vil, Jafar, Evil Queen, and Maleficent.

KING BEAST. (Angrily) Maleficent! She's the worst villain in the land!

PRINCE BEN. Dad, just hear me out here.

KING BEAST. I won't hear of it! They are guilty of unspeakable crimes. (Descendants, 2015).

King Beast and Belle's reactions show that they label the villainous characters as evil. Because of this, King Beast and Belle have certain expectations and prejudices against the villainous characters even though Prince Ben explains that he would invite the children and not the parents. King Beast's insistence to refer to the parents instead to the children shows that he expects the children would also inherit the evil deeds of the parents. His inability to separate the children from the parents' deeds proves that the label he gives them come with his prejudices against them. As Prince Ben does not put any label on the evil characters, thus, he has no prejudices.

On the other side, the villainous characters accept the label of evil, which could be seen in the quotation below where Maleficent questions her fellow villains' rejection in sending their children to Auradon.

CRUELLA DE VIL. They're not taking my Carlos coz I'd miss him too much. $[\ldots]$ Who would touch up my roots, fluff my furs, and scrape the buttons off my feet? (Raises her leg and places it on Carlos' arms.)

JAFAR. Well Jay isn't going either. I need him to stock the shelves in my store.

EVIL QUEEN. Evie's not going anywhere until we get rid of this unibrow (Touches at Evie's eyebrows lightly.)

MALEFICENT

What is wrong with you all? People used to cower at the mention of our names! (Descendants, 2015)

Maleficent's reaction comes out of her disappointment in seeing her fellow villains become mellow and do not show any interest in living up to their evil status. This shows that Maleficent is still proud of her label as an evil villain since it gives all villains power to do anything to achieve their desires as well as making others to be afraid of them. Because of these advantages, Maleficent expects that all villains should live up to their evil status no matter what, and gets angry when they become mellow. Maleficent's anger toward her friends' behavior proves that the acceptance of the label of evil comes with the obligation to live up to it.

\section{Royal Children as Good Children}

All of the royal children gain their parents' label of good, the belief that the villainous characters are evil. Nevertheless, only some of the royal children accept their parents' belief. By accepting this belief, some of the royal children are influenced in seeing the villainous characters as evil, and develop prejudice regarding everything associated to the villainous characters as evil. This could be seen in the quotation below where Princess Audrey, daughter of Princess Aurora and Prince Phillip, criticizes Prince Ben's, decision in bringing the children of the villainous characters to Auradon. 
Prince Chad points at Mal's locker that has a huge picture of Maleficent's silhouette with the words 'Long Live Evil' painted on it to Prince Ben and Princess Audrey.

PRINCE CHAD.

That kid's in trouble.

PRINCE BEN.

(To Prince Chad) Come on, Chad, just give them a chance.

Princess Audrey lifts up her sunglasses and takes Ben's hands.

PRINCESS AUDREY. No offense, Benny Bear, but you're just too trusting. Look, I know your mom fell in love with a big nasty beast that turns out to be a prince. But with my mom, the evil fairy was just the evil fairy. (Glances at Mal and whispers harshly) That girl's mother.

PRINCE BEN. I think you're wrong about them. (Descendants, 2015)

Princess Audrey's criticism comes out of her prejudice that is based on her parents' past encounters with Maleficent. Since she knows that her parents' lives were ruined by Maleficent, Princess Audrey labels the evil fairy as an evil person and has certain prejudices against the daughter, Mal, by seeing her as an evil person. Princess Audrey's inability to separate Mal from Maleficent proves that her perception is influenced by her parents' past encounters that lead her to develop prejudice to everything related to the villains.

Another group of royal children refuses to believe that the villainous characters as evil because they believe that no matter how evil people are, they could be good. This belief then provides a new perspective toward the children of the villainous characters by making the royal children see them not as evil beings. This could be seen in the quotation below where Prince Ben decides to invite the children of the villainous characters to live in Auradon.

Prince Ben stares at the Isle of the Lost with a sorry look on his face as the tailor measures his arm and head.

King Beast and Belle enter his room

PRINCE BEN. $\quad[\ldots]$ Mom, Dad, I've chosen my first official proclamation. I have decided that the children on the Isle of the Lost be given a chance to live here in Auradon.

BELLE. (Disbelief) Huh? (Drops a blue vest)

PRINCE BEN. Every time I look out to the island, I feel like they've been abandoned. [...] We start out with a few at first, the ones who need our help the most. I've already chosen them.

KING BEAST. Have you?

BELLE.

(Holds Beast arm) I gave you a second chance. (Descendants, 2015)

Prince Ben's pity toward the children of the villainous characters derives from his belief that the children could be good or evil depending on which society they live in. This belief then hinders Prince Ben to see the children of the villainous characters as children who need his help in being better individuals, and therefore triggers his decision to bring them to Auradon.

\section{Villains' Children as Evil Children}

On the other hand, the villainous characters, who receive the label of evil, pass down their label of evil and their evil belief to their children. To do this, they use two ways. First of all, the villainous characters elaborate all of the advantages in being evil. This could be seen in the quotation below where Maleficent sings a song entitled Evil Like Me to her daughter, Mal, in order to convince her daughter that evil is the best way to live.

MALEFICENT. Don't you wanna be evil, like me? Don't you wanna be mean? Don't you want to make mischief your daily routine? Well you can spend your life attending to the poor. But when you're evil, doing less is doing more. (Descendants, 2015)

In this song, she implies that being bad is more beneficial than being good. She compares good deeds, shown in the lyric "you can spend your life attending to the poor," with evil deeds in the lyric "but when you're evil doing less is doing more." These two lyrics states that evil offers an easier way to live since the villains do not have to do lots of things to get what they want. They do 
not even have to worry about other people's fate. Instead, they could just focus on their desires and do anything to fulfill them.

Second, the villainous characters try to instill their evil values to their children by showing them how to behave as evil people. This could be seen in the quotation below where Maleficent performs disgusting acts to a child's lollipop to show the difference between mean and evil act.

Mal sees a baby passes in front of her while holding a lollipop. She immediately snatches the lollipop from him and laughs with her friends.

Maleficent comes with her minions.

Mal turns to Maleficent.

MAL.

Hi, Mom.

MALEFICENT. Stealing candy, Mal? So disappointing.

MAL.

But it's from a baby.

Mal hands the lollipop to Maleficent.

MALEFICENT. (Happily) That's my nasty little girl.

Maleficent spits on the lollipop, squeezes it under her armpits, and hands it to her minions. Mal's smile fades.

MALEFICENT. (To her minions) Give it back to the dreadful creature.

MAL.

MALEFICENT.

(Rolls her eyes.) Mom!

It's the deeds, Mal, that makes the difference between mean and truly evil. (Smiles and waves to the baby who is holding his lollipop.) (Descendants, 2015).

When Maleficent finds out that Mal steals a lollipop from a baby, she praises her a little before performing another disgusting acts. This shows that although Maleficent approves of her daughter's effort to perform evil deeds, she is still not satisfied enough with it. In other words, she still considers her daughter's act as just mere mean act that is nothing compared to an evil act. Therefore, to make her daughter understand the ways to be evil, Maleficent places herself as Mal's evil role model and use the power of example to make her understand the ways to be evil.

The teaching of evil deeds is at first accepted by the children of the villainous characters because they want to please their parents by trying to be evil like them. Therefore, they try to convince themselves that they are evil children through chanting, which is seen in the song Rotten to the Core that they sing.

MAL.

JAY.

EVIE.

CARLOS.

Together.

MAL and EVIE.

Together.
They say I'm trouble, they say I'm bad, they say I'm evil, and that makes me glad.

A dirty no good down to the bone. Your worst nightmare, can't take me home.

So I've got some mischief in my blood. Can you blame me? I never got no love.

They say I'm callous, a low life hood. I feel so useless.

Misunderstood.

Mirror, mirror on the wall, who's the baddest of them all? Welcome to my wicked world. Wicked world.

I'm rotten to the core, rotten to the core. I'm rotten to the core who could ask for more? I'm nothing like the kid next, like the kid next door. I'm rotten to the core. (Descendants, 2015)

The villainous children's inability to separate evil qualities from themselves comes from receiving their parents teaching on evil qualities such as growing up in an evil society. Since they belong to the evil category and associate with evil people, the villainous children then shape their identities into evil children. Therefore, the children's identities are formed through the social groups they belong.

\section{Villains' Children Transformation}

When they move to Auradon, the children of the villainous characters encounter with good people who teach them good qualities. These interactions with good people then bring its impacts to each of the children of the villainous characters, and eventually cause them to forget their evil 
status and become good children. This could be seen when Prince Ben tells her that she is good, Mal starts to question her status as an evil villain, which could be seen in the quotation below.
MAL. [...] And now you're gonna be king.
PRINCE BEN. [...] A crown doesn't make you a king.
MAL.
Well, it's kinda does.
PRINCE BEN.
No... (Smiles as he looks down for a moment, before lifting up his head and looks at Mal) Your mother is mistress of evil, and I've got the post of parents of goodness. But we're not automatically like them. We get to choose who we're gonna be. And right now, (Looks at Mal's eyes intently as he inches closer) I can look into your eyes and I can tell that you're not evil. I can see it.

Mal looks at Prince Ben with a surprise look on her face as she gapes at him. (Descendants, 2015.)

As soon as Prince Ben states that not all things could be inherited from their parents, Mal immediately denies it. Her reaction comes out of her belief that she is an evil person that she develops through both her mother's evil status and her upbringing in the Isle of the Lost. Mal's insistence on emphasizing that Prince Ben is different from her proofs that their identities are determined from the labels they receive from their parents as well as the social groups they belong. However, when Prince Ben states that she is different from her mother, Mal begins to see herself from Prince Ben's perspective toward her.

\section{CONCLUSION}

From the story of Descendants, I find that there is an inconsistency between good and evil because Disney shows both the advantages of good and evil. Specifically, Disney states that being good is always rewarded although it may be boring, while being evil is fun because it causes the villains to live freely. However, I find that even though being good is boring and being evil is fun, Disney still sticks to the morality that good will always win. Through the ways that the villainous characters' children should convert to good before they could live happily, it could be seen that Disney is obliged to guide the audience towards positive attitude and good ethics by teaching morality.

\section{REFERENCES}

Descendants. Dir. Kenny Ortega. Perf. Dove Cameron, Sofia Carson, Booboo Stewart, and Cameron Boyce. Disney Channel, 2015. DVD.

Gecas, V. (1982). The self-concept. Annual Reviews Stable: Annual Review of Sociology, Vol. 8 (1982), pp. 1-33. Retrieved from http://www.jstor.org/stable/2945986

Hjalmarsson, R., and Lindquist, M.J. (2012). Like godfather, like son: exploring the intergenerational nature of Crime. The Board of Regents of the University of Wisconsin System : The Journal of Human Resources, (2012), 47(2), 550-582

Islam, G. (2014). Social identity theory. Research Gate, (2014), pp. 1781-1783

Retrieved from https://www.researchgate.net/publication/281208338 